The Polish Journal of the Arts and Culture. New Series 13

(1/2021): 219-224 [RECENZJA]

DOI: $10.4467 / 24506249$ PJ.21.012.13739

\title{
Jakub Sliwa The Silent Mantra Wydanie autorskie, Deadpxels, Kraków 2020, s. 80, 54 opisane fotografie
}

\author{
Przemysław SKRZYŃSKI
}

PrzemysŁaw Skrzyński, religioznawca, buddolog, redaktor, doktorant w Szkole Doktorskiej Nauk Humanistycznych Uniwersytetu Jagiellońskiego. Jego zainteresowania badawcze dotyczą historii buddyzmu w Polsce, przygotowuje rozprawę doktorską na temat pierwszej polskiej wspólnoty buddyjskiej.

E-MAIL: przemyslaw.skrzynski@doctoral.uj.edu.pl

The Silent Mantra („Cicha mantra”) jest autorskim albumem fotografa i orientalisty Jakuba Śliwy, absolwenta filologii orientalnej na Uniwersytecie Jagiellońskim oraz Szkoły Filmowej w Łodzi. Autor, specjalizujący się w subkontynencie indyjskim, wykłada fotografię w Collegium Da Vinci w Poznaniu oraz organizuje i prowadzi wyprawy fotograficzne.

Recenzowany album poświęcony jest niezwykłemu regionowi indyjskiego Ladakhu. Jego geopolityczne położenie (zachodni skraj Wyżyny Tybetańskiej), od wieków będące punktem trwałych i czasowych wpływów kultur Indii, Tybetu i Chin, wciąż należy do jednych z „najbardziej konfliktogennych” miejsc świata. Przylegające do niego terytorium Dżammu i Kaszmiru to ognisko zapalne sporu muzułmańsko-indyjskiego, a wciąż (od 1962 r.) nieuregulowana granica $\mathrm{z}$ Chinami w Ladakhu prowokuje obie strony do jej naruszania. Ostatnia, zbrojna eskalacja indyjsko-chińskiego konfliktu nastąpiła w czerwcu 2020 r. w dolinie rzeki Galwan. 
Dla autora The Silent Mantra Ladakh, to jednak przede wszystkim region, gdzie buddyzm tybetański, którego wyznawcy stanowią większość, zachował się w swojej dość tradycyjnej formie. Niemniej Jakub Śliwa ma przeczucie nieuchronności zmian, które czekają kulturę tego regionu: „Ostatnim bastionem ladakhijskiej tradycji są wioski położone z dala od turystycznych szlaków oraz klasztory, w których odbywają się np. tańce czam. Lecz niestety wiele religijnych świąt powoli traci swój duchowy charakter i przekształca się w komercyjne festiwale turystyczne" (s. 5) - czytamy we wstępie autorstwa samego fotografa. Album ten jest poświęcony udokumentowaniu odchodzącego świata Ladhakijczyków.

Kilkustronicowy tekst wstępu w reporterskim stylu wprowadza czytelnika $\mathrm{w}$ osobiste doświadczenia fotografa $\mathrm{z}$ jego podróży do regionu położonego na północy Indii, ale dostarcza też garść niezbędnych faktów historycznych i geopolitycznych. Niestety, pewne informacje tam zawarte zdezaktualizowały się. Autor pisze m.in.: „Ladakh (jako część Kaszmiru) cały czas pozostaje terytorium spornym...” (s. 3). Od lat 40. XX wieku Kaszmir pozostaje pod konstytucyjną jurysdykcją Indii. Aż do niedawna zachowywał daleko idącą autonomię, z wyjątkiem takich kwestii, jak polityka zagraniczna czy obronna, jednak 31 października 2019 r. Indie uchyliły zapis administracyjny dotyczący tego regionu i przeorganizowały stan, dzieląc go na dwa terytoria związkowe: Dżammu i Kaszmir na zachodzie (z większością muzułmańską i własnym organem przedstawicielskim) i Ladakh na wschodzie (z większością buddyjsko-hinduistyczną, bez organu przedstawicielskiego). Od tego momentu o przynależności Ladakhu do Kaszmiru możemy mówić jedynie w kontekście historycznym. Sytuacja, rzecz jasna, zaogniła konflikt Indii z Pakistanem, którego wpływy na sporny region diametralnie zmalały, a także z Chinami, o czym wspomniano już wcześniej. Śliwa poświęca pewną część wstępu zmianom, jakie zachodzą w społeczności ladakhijskiej na skutek turystycznego i gospodarczego otwarcia. Wiele wskazuje na to, że zasygnalizowane tam problemy pogłębią się, a Ladakh czeka kolejna fala napływowa, tym razem przedstawicieli krajowych biznesów. Nowy status znosi bowiem dotychczasowy zakaz nabywania dóbr majątkowych przez osoby spoza stanów Dżammu i Kaszmir, które zostaną także dopuszczone do pracy w lokalnej administracji i do studiowania na tamtejszych uczelniach. Wszystko to do tej pory było zastrzeżone wyłącznie dla autochtonów.

Wspomnieć też należy o drobnej potyczce historycznej. We wstępie (także s. 3) pojawia się informacja, że „w roku 842 [Ladakh] trafił pod wpływy tybetańskie, powstała dynastia ladakhijska [...] zapoczątkowana przez 
tybetańskiego księcia Nyima Gona w IX w.” Kyide Nyima Gön (rozpoczął panowanie ok. 911 r.) najechał i podbił region Purang (zajmowany dziś przez północny Ladakh) ok. 917 r., gdzie ustanowił siedzibę późniejszej dynastii królów, tzw. Trzech Gön Północnego Tybetu. Sam rządził tym terenem do swojej śmierci ok. 950 r., a więc w wieku X. Rok 842 (lub według innych źródeł 846), o którym mowa w tekście Śliwy, odnosi się zapewne do daty zamordowania Langdarmy (ur. ok. 803), tybetańskiego króla i pradziadka Nyimy Göna.

Kończąc wątek tekstowego wprowadzenia do albumu, wspomnę jeszcze o pewnej idei, której autor stara się być wierny w swojej pracy. W jednym z wywiadów Jakub Śliwa określił się jako adept „świadomego podróżowania”, które definiuje jako postawę unikania ingerencji w kulturowy, ekonomiczny i ekologiczny habitat odwiedzanego miejsca. W kontekście otwarcia granic Ladakhu dla masowej turystyki fotograf prezentuje pogląd, który wydaje się stanowić wypadkową koncepcji „szlachetnego dzikusa” Jean-Jacquesa Rousseau i legendy o zaginionym buddyjskim królestwie Śambhali: „Szczęśliwe do tej pory [1974] społeczności, żyjące w harmonii z naturą, w pełni samowystarczalne, nieznające przemocy, stresu, przestępczości oraz innych plag cywilizacyjnych zaczęły przechodzić nieodwracalne zmiany” (s. 3). Natomiast odnośnie do organizowanych przez siebie grupowych wyjazdów fotograficznych mówi następująco: „(...) zacząłem się zastanawiać, czy organizując wyprawy do dziewiczych miejsc, pokazując ludziom rzadkie obrzędy religijne lub lokalne magiczne rytuały plemienne, sam nie uczestniczę $\mathrm{w}$ tym procederze. Dlatego staram się nie wracać w te same tereny, zabieram ze sobą tylko kilka osób i nie wszystkie miejsca ujawniam z nazwy, aby ich nie «spalić»". Nietrudno znaleźć argumenty polemiczne wobec tak ujętego stanowiska, zwłaszcza że efekt ladakhijskiej wyprawy - omawiany album w kontekście „świadomego podróżowania” stanowi pewną dokumentację, ale zdecydowanie bardziej w sensie komercyjno-popularyzatorskim niż naukowym. Przejdźmy jednak do sedna, czyli do samych fotografii. Jakub Śliwa jest obiektywnym dokumentalistą, pragnącym zachować w kadrze coraz mniej uchwytny kawałek kultury świata. Jednocześnie, co jako odbiorcy wyjątkowo mocno odczuwamy, chce być także uczestnikiem wydarzeń - życia społecznego i religijnego Ladakhijczyków. Większość zdjęć charakteryzuje intymna atmosfera spotkania, czego symptomem jest fakt, że autor rzadko prezentuje ujęcia z dystansu. Śliwa fotografuje buddyjskich pielgrzymów wykonujących pokłony podczas rytualnej kory, pogrążonego w skupieniu młodego człowieka, zapalającego maślaną lampkę, podpatruje modlących 
się mnichów z ważnego dla historii buddyzmu tego regionu, klasztoru Shey. Album otwiera portret mnicha z klasztoru Spituk, dla którego tło stanowi fresk przedstawiający Koło Życia. Wybór znamienny, biorąc pod uwagę, że jednym głównych tematów albumu jest nietrwałość - buddyjska anicca (tyb. mi rtag pa).

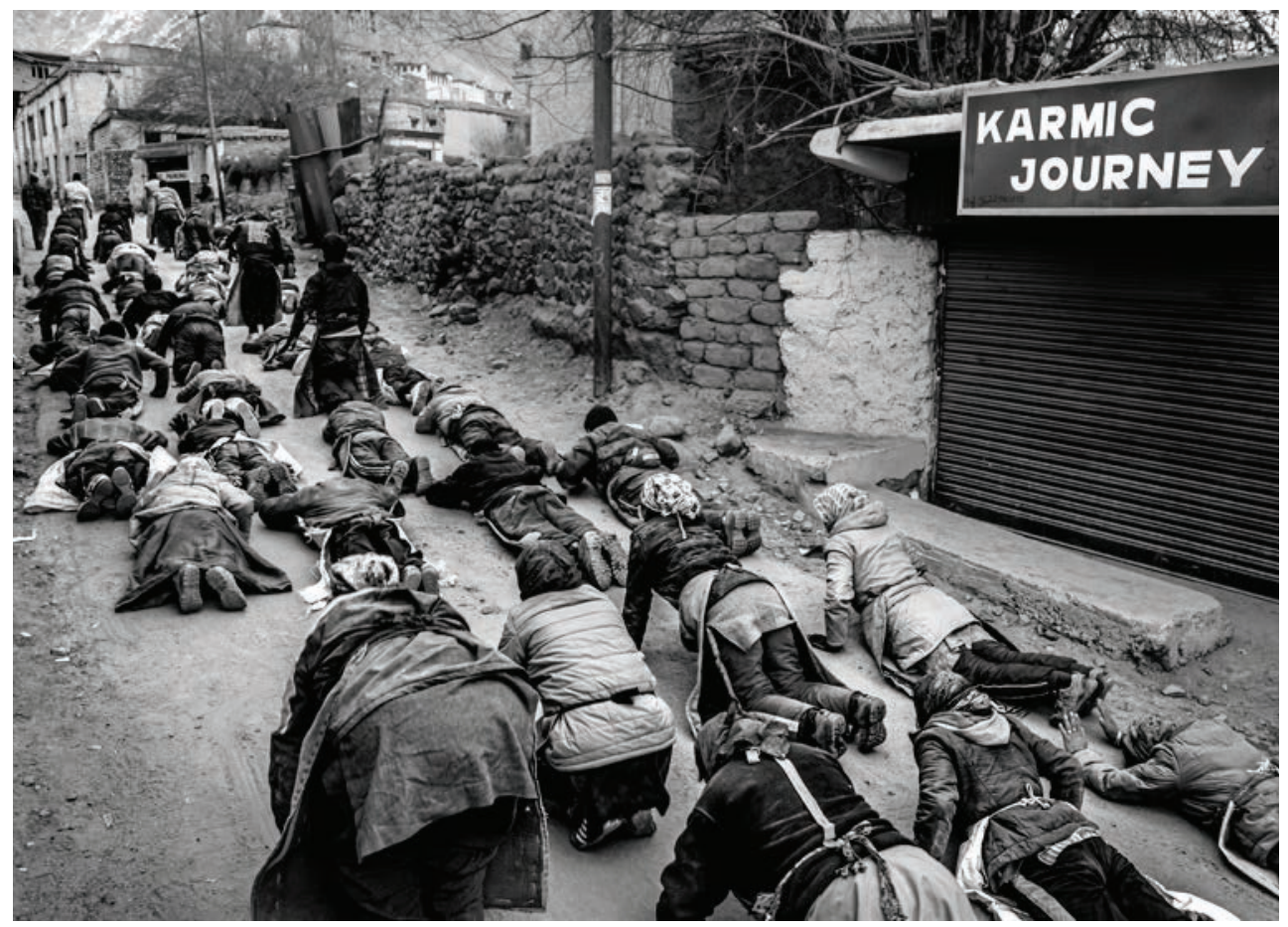

Zdjęcie 1. Karmic Journey. Ulica w Leh. Wierni wykonują prostrację, bijąc pokłony, przemierzają trasę pielgrzymki

Co odróżnia omawiany album od znanych zdjęć tego regionu autorstwa Erica Valli, Steva McCurry czy Marka Kalmusa? Każda z 54 fotografii zamieszonych w The Silent Mantra jest utrzymana w tonacji czerni i bieli. Zabieg nietypowy wśród fotografów kultur himalajskich, głównie ze względu na atrakcyjność intensywności barw, przeważających zarówno w naturalnym krajobrazie, jak i w wytworach kultury tamtego terenu. Jakub Śliwa swoją monochromatyczną estetyką idzie nieco na przekór, pozwalając z jednej strony działać wyobraźni widza, z innej zaś „oddać okiem artysty ulotną atmosferę buddyjskiej filozofii, unikalnej kultury i odosobnienia”. Przyzwyczajeni do pewnej narzuconej przez magazyny podróżnicze maniery, która eksponuje 
zawsze estetycznie atrakcyjne, ale artystycznie zgrane ujęcia i tematy, w The Silent Mantra otrzymujemy fotografie skupione na innych jakościach: nastrojowości i tajemniczości. Służyć mają temu cechy fotografii czarno-białej - eksponowanie roli światła, bardziej wyrazista faktura rejestrowanych obiektów, oszczędność, szlachetność, głębia itd. Formalnie zdjęcia Śliwy charakteryzuje

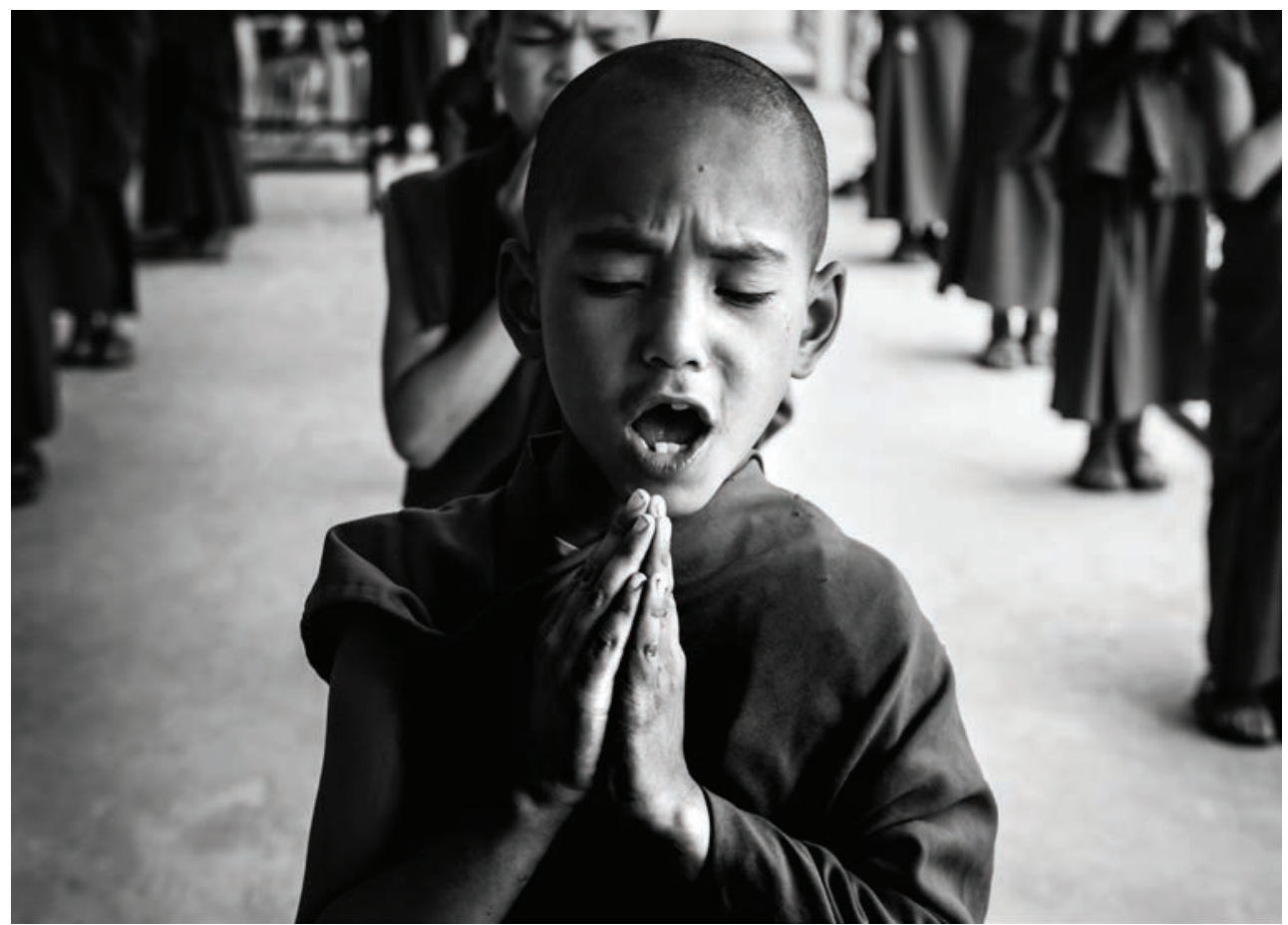

Zdjęcie 2. Poranna modlitwa w szkole przyklasztornej w Likir

duży stopień kontrastowości - intensywna gra pomiędzy słabym a mocnym nasyceniem czerni. Niestety, w połączeniu z matowym, niepowlekanym, kremowym papierem, na którym został wydrukowany album, końcowy rezultat jest wątpliwy. Zdjęcia tracą ostrość, gubi się szczegół, zwłaszcza tam, gdzie detal wydaje się budować pewną narrację (vide wspomniany portret mnicha z klasztoru Spituk). Niektóre z prezentowanych w albumie fotografii istnieją w wersji barwnej, o czym można się przekonać, przeglądając internetowe strony poświęcone artyście. Po obejrzeniu zdjęć w takiej formie można dojść do wniosku, że na ostateczny efekt wpływają czarno-biała estetyka i wybór papieru. Można się pokusić o pytanie, czy na pewno pozytywnie. 


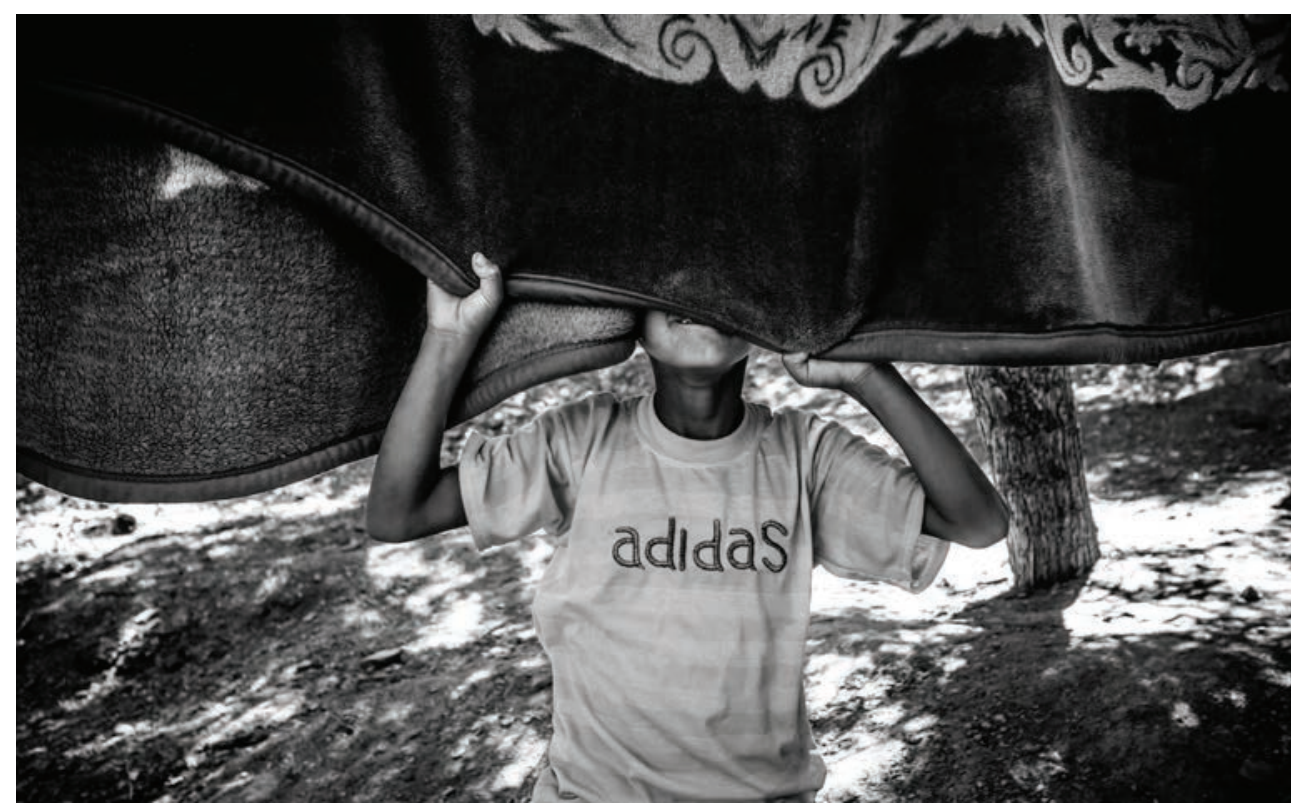

Zdjęcie 3. Kolega mnicha, który nie chce pokazać twarzy. Ogród przy klasztorze w Alchi

Album The Silent Mantra Jakuba Śliwy jest interesującym dokumentem popularyzującym wiedzę o słabo w naszym kraju znanym buddyjskim regionie Indii. W minionym $2020 \mathrm{r}$. opublikowana została także książka $\mathrm{z}$ fotografiami autorstwa prof. Andrzeja Strumiłły, który wędrował po północnych krajach i regionach buddyjskiego kręgu kulturowego (choć nie po Kaszmirze) już w latach 50. XX w. Zestawienie zdjęć z obu publikacji nie tylko uwiarygodnia autentyczność tradycji zarejestrowanych przez Śliwę, ale i daje nadzieję, że kultura Ladakhu nie zniknie w ciągu kolejnych 70 lat i dłużej. 